\title{
KETENAGAAN DI TAMAN BACAAN MASYARAKAT (STUDI PENDAHULUAN)
}

\begin{abstract}
B.P Sitepu
Abstract

Reading skill and reading habit should be developed in all levels of society in establishing reading and learning society which can not be avoided in this modern age. The Community Reading Centers $(C R C)$ which have been developed since nineteen fifties are expected to stimulate the establishment and the development of reading societies all over Indonesia. The Government has provided some grants and facilities to empower the Centers to activate their functions. As the expectation for these centers is so great, this preliminary study made a close observation on four Centers located in Medan, North Sumatra. Attention was focused on the number and quality of man power serving the attendants in each Center. It is believed, the manpower plays a significant role in the operation of the Center to do its function to reach the predetermined goals. This preliminary study finds out that the quality of the manpower in the four Centers influence the quality and quantity of the services provided. The Center with experienced and active personnel is able to complete its function better than the ones with lack of experiences and initiatives. This study suggests the Government to give priority to training program in empowering the Centers.
\end{abstract}

Key words: Community Reading Center, reading society, reading habit, personnel, reading facility.

\section{PENDAHULUAN}

\section{Latar Belakang Masalah}

Salah satu tujuan kemerdekaan bangsa Indonesia ialah mencerdaskan kehidupan bangsa yang dilakukan melalui pendidikan baik pendidikan formal, nonformal, maupun informal. Melalui pendidikan itu, diharapkan setiap orang memperoleh pengetahuan, keterampilan, dan sikap yang dapat dipergunakan sebagai modal untuk meningkatkan kemampuannya mengatasi berbagai masalah sehingga secara mandiri atau bersama-sama dapat meningkatkan mutu kehidupannya menjadi lebih sejahtera dan makmur secara jasmani dan rohani sampai akhir hidupnya. Untuk kepentingan tersebut, maka setiap orang perlu terus menerus meningkatkan kemampuannya melalui belajar sehingga proses belajar itu sendiri berlangsung sepanjang hayat. Agar dapat belajar secara mandiri dan tidak selalu tergantung pada orang lain, setiap individu perlu menguasai dan menerapkan cara belajar yang efektif dan efisien.

Manusia dapat belajar melalui berbagai sumber, seperti dari orang lain, lingkungan, serta berbagai media

* Guru Besar Universitas Negeri Jakarta cetak dan elektronik. Salah satu cara yang cukup praktis dan murah ialah belajar melalui membaca berbagai jenis bahan yang tertulis atau tercetak. Kegiatan membaca itu dapat dilakukan di mana saja dan kapan saja sesuai dengan kesempatan yang ada. Bahan bacaanpun relatif mudah diperoleh dengan meminjam atau membeli. Akan tetapi untuk dapat melakukan itu, orang perlu memiliki kemampuan membaca.

Mengingat pentingnya kemampuan membaca untuk belajar menambah pengetahuan, keterampilan, dan sikap maka Pemerintah sejak Indonesia merdeka berupaya memperluas kesempatan belajar bagi semua Warga Negara Indonesia, baik melalui pendidikan formal maupun melalui pendidikan nonformal. Program pemberantasan buta huruf/aksara dilaksanakan dan ditingkatkan untuk menjangkau mereka yang masih belum mampu membaca, menulis, dan berhitung karena berbagai alasan.

Di samping memberikan kemampuan membaca, berbagai upaya dilaksanakan oleh Pemerintah dan pihak swasta untuk menumbuhkan minat dan kebiasaan membaca masyarakat sehingga menjadi salah satu kebutuhan hidup dan pada waktunya akan menjadi salah satu identitas dan unsur budaya bangsa. 
Sekalipun demikian, budaya baca tulis masyarakat Indonesia masih belum berkembang secara menggembirakan. Warisan budaya lisan yang masih menganggap penyampaian pesan yang diucapkan lebih penting dan lebih menarik daripada yang tertulis, masih hidup di tengah-tengah masyarakat. Kenyataan ini terlihat dalam kehidupan sehari-hari, baik di masyarakat perkotaan maupun di masyarakat pedesaan.

Pada awal tahun lima puluhan telah berdiri dan berkembang Taman Pustaka Rakyat (TPR) yang didirikan oleh Pendidikan Masyarakat. TPR yang bertujuan untuk meningkatkan minat dan kegemaran membaca masyarakat dengan memberikan pelayanan bahan bacaan. TPR ini kemudian pada tahun 1992/ 1993 berkembang menjadi Taman Bacaan Masyarakat (TBM) yang tugas pokoknya ialah menyediakan berbagai jenis bahan bacaan dalam membangun masyarakat gemar membaca dan gemar belajar (Direktorat Pendidikan Masyarakat, 2006:1).

TBM dapat didirikan, dikelola, serta dibiayai oleh masyarakat, pemerintah daerah, atau masyarakat bekerja sama dengan pemerintah daerah. Seperti namanya, lokasi TBM ini biasanya berada dekat dengan pemukiman atau kegiatan masyarakat. Persyaratan pembentukannya yang tidak ketat, tata cara pengelolaannya yang luwes dan tidak terlalu formal merupakan ciri yang membedakannya dengan perpustakaan.

Di jalur pendidikan nonformal keberadaan TBM dianggap sangat strategis dan merupakan ujung tombak dalam memasyarakatkan gemar dan kebiasaan membaca sehingga menjadi salah satu ciri kebudayaan masyarakat setempat. Oleh karena itu, Pemerintah berupaya mengembangkan dan memberdayakan TBM sehingga menjadi wadah yang mampu menyediakan berbagai bahan belajar yang dibutuhkan masyarakat serta sekaligus sebagai tempat penyelenggaraan pembinaan kemampuan membaca dan belajar serta tempat untuk mendapatkan berbagai informasi yang diperlukan masyarakat. Oleh karena itu, TBM perlu dikelola oleh mereka yang memiliki dedikasi dan kemampuan teknis dalam mengelola dan melaksanakan layanan kepustakaan kepada masyarakat di samping menyediakan berbagai jenis bahan bacaan.

Dalam buku Pedoman Pengelolaan TBM yang diterbitkan Direktorat Pendidikan Masyarakat (2006:12), disebutkan bahwa tujuan utama TBM adalah untuk: (1) membangkitkan dan meningkatkan minat baca masyarakat sehingga tercipta masyarakat cerdas yang selalu mengikuti perkembangan ilmu pengetahuan dan teknologi, (2) menjadi sebuah wadah kegiatan belajar masyarakat, dan (3) mendukung peningkatan kemampuan aksarawan baru dalam Pemberantasan Buta Aksara sehinga tidak menjadi buta aksara kembali. Mengacu pada tujuan itu maka TBM diharapkan berfungsi sebagai: (1) sarana pembelajaran bagi masyarakat, (2) sarana hiburan (rekreasi) dan pemanfaatan waktu secara efektif, dan (3) sarana informasi berupa buku dan bahan bacaan lain yang sesuai dengan kebutuhan warga belajar dan masyarakat setempat.

Pembudayaan masyarakat menjadi tidak hanya gemar bahkan gandrung membaca memerlukan upaya yang sungguh-sungguh, baik dari pihak Pemerintah maupun masyarakat sendiri. Mengingat pengembangan dan peningkatan kegemaran membaca terkait dengan bahan pustaka, maka gerakan nasional gemar membaca menjadi tugas dan tanggung jawab Perpustakaan Nasional (RUU Perpustakaan, Pasal 17). Akan tetapi, belajar untuk mampu dan terampil membaca yang dilakukan secara terus menerus sehingga menjadi kebiasaan orang perseorangan dan pada akhirnya akan menjadi budaya masyarakat tidak dapat dipisahkan dari proses pembelajaran di lembaga pendidikan formal dan nonformal.

Sehubungan dengan hal tersebut di atas, maka dalam pengembangan organisasi Departemen Pendidikan Nasional pada tahun 2005, Pemerintah membentuk unit kerja di lingkungan Direktorat Jenderal (Ditjen) Pendidikan Luar Sekolah yang bertugas mengembangkan budaya baca masyarakat melalui TBM sebagai pusat sumber informasi dan pembelajaran masyarakat, terutama bagi mereka yang tinggal di daerah pedesaan dan kawasan miskin perkotaan. Sedangkan satuan pendidikan formal berperan membina dan mengembangkan kegemaran membaca peserta didik, baik melalui kegiatan pembelajaran maupun melalui optimalisasi pendayagunaan perpustakaan yang ada.

Keberhasilan Pemerintah dan masyarakat memberantas buta aksara dan meningkatkan jumlah penduduk Indonesia yang memiliki kemampuan membaca, menulis, dan berhitung perlu terus dibina dan ditingkatkan, khususnya bagi mereka yang merupakan aksarawan baru dan yang sudah keluar dari jalur pendidikan formal. Ketiga kemampuan dasar itu sangat diperlukan untuk memperoleh dan mengembangkan penguasaan ilmu pengetahuan, teknologi, dan seni serta meningkatkan akhlak manusia sepanjang hidupnya. Ketiga kemampuan itu juga merupakan modal dasar bagi setiap orang untuk dapat belajar secara mandiri membangun dirinya sendiri dan memperbaiki tingkat kehidupannya sehingga dapat 
hidup layak, sehat, dan mempunyai harapan hidup yang lebih panjang.

Berbagai bentuk bantuan telah diberikan oleh Pemerintah dan pemerintah daerah kepada TBM baik dalam bentuk dana, bahan bacaan, dan pemberdayaan tenaga pengelola TBM melalui penyediaan pedoman pedoman, pelatihan, lokakarya, dan seminar. Sungguhpun penumbuhkembangan minat dan kegemaran membaca serta pembentukan masyarakat yang gandrung dan berbudaya baca memerlukan waktu yang cukup lama, hasil yang diperoleh sampai sekarang ini kelihatannya belum semaju yang diharapkan.

Berdasarkan hasil pengamatan singkat dapatlah dikatakan bahwa kecenderungan yang dilakukan oleh anggota masyarakat Indonesia, baik sebagai individu maupun kelompok, apabila sedang berada: (a) di tempat penantian (ruang tunggu), yaitu di stasiun kereta api, terminal atau halte bus, di rumah sakit/praktek dokter/ apotek; (b) dalam perjalanan, misalnya di kereta api, bus atau pesawat udara; atau (c) dalam keadaan santai di tempat rekreasi, pada umumnya cenderung untuk "tidak berbuat apa-apa (idle)", kecuali hanya menikmati pemandangan alam sekitar, berdiam diri, mengobrol dengan orang yang berada di dekatnya, atau menyibukkan diri dalam permainan elektronik melalui telepon genggam.

Hasil survei Litbang Kompas (2005) yang berkaitan dengan intensitas membaca, menunjukkan kegiatan membaca masih belum menggembirakan perlu dicatat bahwa survei yang melibatkan 786 responden berusia minimal 17 tahun tersebut bukan mewakili seluruh masyarakat Indonesia, tetapi hasilnya dapat memberikan gejala tentang aktivitas membaca di Indonesia. Hasil survei itu menunjukkan intensitas responden membaca sebagaimana yang tertera dalam tabel 1 berikut.

Tabel 1

\section{Intensitas Responden Membaca}

\begin{tabular}{|l|l|r|l|l|l|r|}
\hline Tingkat & \multicolumn{5}{|c|}{ Intensitas Responden Membaca } & \multirow{2}{*}{ Total } \\
\cline { 2 - 7 } & Tiap hari & $\begin{array}{l}4-6 \text { kali } \\
\text { seminggu }\end{array}$ & $\begin{array}{l}1-3 \text { kali } \\
\text { seminggu }\end{array}$ & $\begin{array}{l}\text { Tdk punya } \\
\text { kebiasaan }\end{array}$ & $\begin{array}{l}\text { Tidak } \\
\text { tahu/jawab }\end{array}$ & \\
\hline Rendah & 14,6 & 0 & 22,0 & 53,7 & 9,8 & 100 \\
\hline Menengah & 23,9 & 6,0 & 38,3 & 29,0 & 2,9 & 100 \\
\hline Tinggi & 35,5 & 13 & 30,7 & 19,5 & 1,4 & 100 \\
\hline & & & & & & \\
\hline
\end{tabular}

Data di atas menunjukkan antara lain bahwa jumlah responden yang melakukan kegiatan membaca setiap hari masih rendah termasuk mereka yang tergolong berpendidikan tinggi (35,5\%). Semakin rendah tingkat pendidikan seseorang, maka semakin rendah pula frekuensi aktivitas membacanya. Bahkan cukup banyak, khususnya yang berpendidikan rendah, yang menyatakan tidak mempunyai kebiasaan membaca. Intensitas membaca untuk mereka yang baru melek huruf atau aksarawan baru mungkin akan lebih memprihatinkan lagi, dan tidak tertutup kemungkinan mereka kembali menjadi buta aksara apabila tidak diikuti dengan pembinaan lebih lanjut.

Indikator lain dapat juga dilihat dari jumlah dana yang digunakan untuk membeli buku. Berdasarkan sumber yang sama (Litbang Kompas, 2005), sebagian besar (88\%) responden tidak menyediakan dana untuk membeli buku. Hanya sebagian kecil responden (12\%) yang menyediakan dana kurang dari Rp100.000 per bulan untuk membeli buku. Dengan demikian, membeli buku tampaknya masih belum merupakan prioritas bagi sebagian besar responden. Oleh karena itu, tidak mengherankan kalau sedikit sekali dari responden
(14,3\%) yang memiliki perpustakaan pribadi di rumah dan bahkan responden yang menjadi anggota perpustakaan pun jumlahnya sedikit (23\%).

Kondisi tersebut di atas akan lebih memprihatinkan lagi bagi kalangan masyarakat yang tergolong miskin atau berada di bawah garis kemiskinan serta mereka yang tinggal di daerah terpencil dan jauh dari kemungkinan mendapat bahan bacaan. Sebagai informasi, jumlah penduduk miskin di daerah pedesaan tahun 2003-2004 adalah 24,78 juta orang dan penduduk miskin di daerah perkotaan 11,37 juta orang. Meskipun hasil survei yang dilakukan oleh Litbang Kompas tersebut tidak dapat digeneralisasikan untuk seluruh masyarakat Indonesia, namun data yang diperoleh dapat dijadikan sebagai gejala atau indikasi tentang belum berkembangnya kegiatan dan kebiasaan membaca menjadi salah satu unsur budaya bangsa.

Dalam leaflet Membaca Jadikan Kualitas Hidup Lebih Baik (Direktorat Pendidikan Masyarakat, 2006), pada tahun 2007 Pemerintah menargetkan menambah 6.000 TBM di seluruh Indonesia sehingga pada awal tahun 2008 terdapat setidak-tidaknya 8.4000 TBM di seluruh Indonesia. Untuk jangka panjang ditargetkan 
setiap desa setidak-tidaknya memiliki satu TBM. Setiap TBM diharapkan dapat berfungsi sebagai mesin penggerak dan fasilitator pembentukan masyarakat gandrung membaca dan belajar.

Besarnya harapan, perhatian, dan bantuan kepada TBM ini mengundang keingintahuan keadaan dan kegiatan yang berlangsung di setiap TBM. Namun, keberhasilan TBM melaksanakan tugasnya untuk mencapai tujuan yang diharapkan bergantung pada tenaga yang ada. Oleh karena itu keadaan tenaga pengelola TBM menarik untuk dicermati dan diketahui. Masalah

Berdasarkan uraian sebelumnya maka masalah perlu diteliti di TBM: (1) sarana apa saja yang dimiliki,
(2) kegiatan apa yang dilakukan, (3) berapa jumlah pengelola, dan (4) bagaimana kemampuan pengelola TBM.

\section{Tujuan Penelitian}

Penelitian yang masih bersifat penelitian pendahuluan (preliminary study) ini bertujuan untuk memberikan gambaran keadaan dan kegiatan TBM dengan memberikan penekanan pada peranan tenaga pengelola TBM. Hasil penelitian ini diharapkan dapat dijadikan sebagai salah satu acuan dalam mengembangkan penelitian sejenis dengan jangkauan yang lebih luas sehingga hasilnya dapat digeneralisasi sehingga bermanfaat dalam merumuskan kebijakan dalam pengembangan TBM secara nasional.

\section{METODOLOGI PENELITIAN}

Oleh karena banyaknya jumlah TBM yang tersebar di seluruh Indonesia dan penelitian ini bersifat penelitian pendahuluan, maka objek penelitian ini dilakukan melalui pengamatan terbatas di empat TBM. Keempat TBM dipilih secara acak di Kotamadya Medan dan tidak dianggap mewakili TBM lainnya di wilayah dan di luar wilayah Kotamadya Medan. Data dikumpulkan melalui wawancara, pengamatan langsung, serta studi dokumen. Pengumpulan data dilakukan dari tanggal 17 sampai dengan 19 Desember 2007. Data disajikan secara deskriptif dan dianalisis berdasarkan pedoman-pedoman penyelenggaraan TBM yang ada. Sesuai dengan tujuan dan sifat penelitian ini, maka tidak dilakukan kajian teori yang mendalam.

\section{HASIL PENELITIAN}

\section{Deskripsi Data}

Berikut ini disajikan secara berurutan data dan informasi yang diperoleh melalui wawancara, pengamatan, dan studi dokumen di (1) TBM EMPHATY, (2) TBM KURSUS KOMPUTER PAKPAK MANDIRI (3) TBM TELADAN, dan (4) LPNF TBM PLUS MAS RADEN. Data dan informasi yang diperoleh mencakup organisasi, sarana, kegiatan, dan tenaga pengelola.

\section{TBM Emphaty}

TBM Emphaty berlokasi di Jl. Jamin Ginting No 408 Padang Bulan, Medan Selayang, dan berada di bawah Pusat Kegiatan Belajar Masyarakat (PKBM) Emphaty yang didirikan oleh Yayasan Empahty, sebuah LSM yang bergerak di bidang pemberdayaan dan pendidikan anak miskin perkotaan. TBM ini mulai beroperasi pada bulan Februari 2002 dan di samping menyelenggarakan TBM, PKBM Emphaty menyelenggarakan program Keaksaraan Fungsional (KF), Pendidikan Anak Usia Dini (PAUD), Paket B dan C, dan Life Skills (Kecakapan Hidup). PKBM ini menempati sebuah gedung berlantai dua berbentuk rumah toko menghadap jalan utama antarpropinsi dan ramai lalu lintas dari luar kota ke arah Medan dan sebaliknya. Bagian depan lantai dasar dipergunakan sebagai ruang belajar dan bagian belakang menuju pintu ke halaman belakang serta di dekat tangga ke lantai dua dipergunakan sebagai Taman Bacaan Masyarakat (TBM). Di tingkat dua, dipakai sebagai kantor Yayasan dan tempat belajar.

Di ruang TBM yang ukurannya empat kali tiga meter itu terlihat satu rak buku dengan enam susun dan ukuran dua kali empat meter, sebuah lemari buku, sebuah televisi, dua kursi, serta satu lemari etalase kaca yang kosong. Tidak terlihat meja untuk membaca dan juga tidak terlihat meja dan kursi untuk petugas TBM. Rak atas buku yang terlihat kusam itu, diisi penuh dengan buku-buku paket B dan C. Kulit dan isi bukubuku itu terlihat bersih dan tidak terlihat tanda-tanda buku itu sering dibaca. Di rak buku lainnya berserakan buku-buku bacaan dan sejumlah majalah terbitan lama. Di lemari buku yang berdebu terlihat beberapa buku dan majalah yang tidak tertata. Seluruh koleksi bahan bacaan berjumlah sekitar 177 judul dengan jumlah secara keseluruhan 364 eksemplar. Sebagian besar dari buku-buku itu adalah buku paket B dan C, serta selebihnya buku dan majalah yang berkaitan dengan aama, wirausaha, kesehatan, pengetahuan populer, dan cerita teladan. Tidak terlihat klasifikasi jenis buku dan identitas kepemilikan buku dan bahan bacaan itu. Juga tidak terlihat kartu katalog atau kartu peminjaman. 
Namun, TBM ini memiliki Daftar Buku TBM, yang berisi data buku seperti tanggal penerimaan buku, nomor induk, judul buku, cetakan, jilid, tahun terbit, dan penerbit buku. Di buku yang ditulis tangan itu tidak tercantum data tentang asal buku. Berdasarkan penjelasan pengelola, buku koleksi TBM itu berasal dari Dinas Pendidikan, Kanwil Departemen Agama Sumatra Utara, dan Gereja setempat dengan perincian: 100 judul dari Dinas Pendidikan, 50 judul dari Kanwil Depag, dan 27 judul dari Gereja setempat. TBM untuk umum dibuka empat hari dalam seminggu, yaitu pada hari Senin, Selasa, Kamis, dan Sabtu.

Ketika pengamatan dilakukan pada hari Selasa (hari operasi/buka TBM), tidak terlihat ada pengunjung ke TBM. Menurut informasi pengelola, rata-rata jumlah pengunjung per hari adalah 10 orang yang semuanya adalah peserta program Paket $\mathrm{B}$ atau $\mathrm{C}$ yang dikelola Yayasan itu. Dalam buku Daftar Peminjam Buku terlihat data pengunjung dari tanggal 15 Januari sampai 3 April 2007 dengan jumlah pengunjung sebanyak 65 orang terdiri atas 15 orang warga belajar Program Paket B dan 50 orang warga belajar Program Paket C. Tidak ada data sebelum dan sesudah periode itu. Juga tidak diperoleh alasan yang jelas mengapa tidak ada data sebelum dan sesudah periode tersebut.

Dalam struktur organisasinya, TBM ini dikelola oleh seorang ibu rumah tangga (isteri Ketua PKBM Emphaty) dengan latar belakang $\mathrm{S} 1$ di bidang ilmu sosial. Ibu tersebut belum pernah memperoleh pelatihan tentang pengelolaan TBM serta tidak pernah memperoleh pengalaman mengelola TBM atau perpustakaan sebelumnya. Dalam struktur organisasi TBM tertera nama ketua, sekretaris, dan pustakawan. Berdasarkan informasi yang diperoleh, belum ada di antaranya yang pernah memperoleh penataran atau pelatihan tentang pengelolaan TBM atau perpustakaan. Dalam kegiatan sehari-hari ketiga orang tersebut lebih banyak membantu kegiatan PKBM di luar TBM.

\section{TBM Kursus Komputer Pakpak Mandiri}

TBM ini diselenggarakan oleh PKBM Pakpak Mandiri milik Yayasan Pakpak Mandiri. PKBM Pakak Mandiri bergerak di bidang pemberdayaan masyarakat dan kecakapan hidup (life skills). TBM ini mulai beroperasi Mei 2005. Semula berlokasi di Jl. Luku I No. 92 dan dalam bulan November 2007 TBM ini pindah ke Jl. Luku I, Gg. Spadan No. 18, di Kelurahan Bekala, Kecamatan Medan Johar. Jarak dari tempat lama ke tempat baru itu sekitar 300 meter, dan alasan perpindahan dari lokasi yang semula menghadap jalan raya ke lokasi perumahan penduduk itu adalah tempat yang semula dikontrak akan dijual oleh pemiliknya. Bangunan yang sekarang ditempati TBM ini berbentuk rumah dengan ukuran $6 \times 10$ meter dan diisi dengan lima buah meja, 30 kursi belajar, 20 perangkat komputer dan dua printer yang dipergunakan untuk kursus komputer, serta sebuah papan tulis.

Yayasan ini juga sedang menyelenggarakan Program Paket A, B, dan C dengan warga belajar secara keseluruhan sebanyak 88 warga belajar dengan perincian 14 warga belajar Program Paket A, 18 warga belajar Program Paket B, dan 56 warga belajar Program Paket C

Tidak terlihat lemari dan rak buku tempat menyimpan bahan bacaan. Pada dinding kiri dan kanan ruangan tergantung rapih puluhan majalah dalam negeri seperti Gatra, Forum, Tempo, Hidup, dan Inti Sari, serta terbitan luar negeri seperti Newsweek dan Sportif. Di samping itu terlihat juga beberapa judul buku Program Paket dan C. Berdasarkan data yang diperoleh, terdapat 85 judul bahan bacaan dengan jumlah keseluruhan 142 eksemplar. Penempatan majalah dan buku dalam posisi tergantung pada dinding sampai mendekati langit-langit itu terlihat seperti "dinding pamer", hanya dapat dilihat kulit luar majalah serta buku dan sulit dapat dijangkau serta diambil karena jaraknya yang cukup tinggi dari lantai. Menurut pengelola, bahan bacaan yang dimiliki TBM itu diperoleh atas usaha sendiri dan tidak pernah mendapat bantuan buku, bahan bacaan lainnya, atau dalam bentuk dana dari instansi Pemerintah atau lembaga swasta, sungguhpun sudah berkali-kali mengajukan proposal untuk memperoleh bantuan dana dan bahan bacaan.

Tidak terlihat daftar judul bahan bacaan koleksi TBM ini tetapi terdapat Buku Peminjaman/ Pengembalian TBM Kursus Komputer Pakpak Mandiri yang berisi daftar pengunjung mulai 12 Juli 2005 sampai dengan 30 Juli 2006 sebanyak 177 orang pengunjung. Data itu ditulis dengan tulisan tangan yang warna tinta dan bentuk tulisan yang sama. Tidak diperoleh data yang jelas mengapa daftar itu tidak diteruskan sesudah periode itu. Menurut pengelola, pengunjung dapat membaca bahan bacaan itu di ruang tempat belajar dan pada umumnya pengunjung adalah warga belajar paket A, B, C, atau peserta kursus komputer. Warga lain hampir tidak pernah datang ke TBM itu. Sewaktu pengamatan, tidak terlihat pengunjung di TBM ini dan hal tersebut menurut pengelola, kegiatan di TBM itu diliburkan mulai 11 Desember 2007 sampai bulan Januari 2008.

Pada struktur organisasi tergambar pengelolaan TBM ini dilakukan oleh seorang kepala, seorang petugas bidang administrasi dan teknis, dan seorang petugas untuk bidang pengelolaan. Sewaktu pengamatan dilakukan, yang ditemukan hanya kepala TBM yang juga pendirinya dengan latar belakang sarjana teknik di bidang pertanian serta bertugas sebagai dosen 
di salah satu perguruan tinggi swasta di Medan. Ketiga pengelola itu belum pernah memperoleh pelatihan atau pendidikan tentang pengelolaan TBM ataupun perpustakaan.

\section{TBM Teladan}

TBM yang berlokasi di kompleks SLTP Al Washliyah 29, Jl. Stadion No. 12, Desa Teladan Barat, Medan ini berdiri pada tahun 1998. TBM yang dikelola oleh PKBM Teladan ini menyatu dengan Perpustakaan SLTP AI Washliyah 29 dan terbuka untuk masyarakat umum. Di sekitar TBM ini terdapat sejumlah sekolah/ madrasah, perguruan tinggi, dan beberapa rumah penduduk, kios, serta kantor. Pada waktu pengamatan, TBM ini menempati ruangan berukuran $5 \times 3$ meter, tetapi menurut informasi yang diperoleh, tempat itu bersifat sementara karena ruangan yang sesungguhnya sedang direnovasi.

Di dalam ruangan terdapat meja dan kursi petugas, dua rak lemari yang panjang, masing-masing memiliki empat tingkat rak. Satu rak buku dipakai untuk buku-buku perpustakaan SLTP AI Washliyah dan satu rak lagi dipakai untuk buku-buku SLTP AI Washliyah dan buku-buku TBM dengan jumlah keseluruhan sebanyak 200 judul buku. Baik buku-buku SLTP AI Washliyah dan buku-buku TBM disusun berdasarkan kelompok isi buku, misalnya buku-buku ilmu murni, buku-buku keterampilan, dan buku agama, buku Program Paket B dan C, serta majalah ilmiah. TBM ini tidak memiliki kursi dan meja baca dengan alasan pengunjung melakukan kegiatan membaca dengan duduk di lantai.

Di ruangan TBM itu terdapat buku Daftar Inventaris Buku TBM PKBM Teladan. Akan tetapi, data dalam Daftar itu tidak lengkap, misalnya tidak terisi nomor urut dan nomor induk buku, tidak tercantum tahun terbit, sumber, harga, dan jumlah eksemplar buku. Dari Daftar buku itu tidak dapat diketahui secara tepat jumlah judul dan eksemplar buku.

Di samping Buku Daftar Inventaris Buku, TBM ini dilengkapi dengan Buku Tamu, dan Buku Peminjaman dan Pengembalian Buku yang terisi mulai 14 September sampai dengan 20 Desember 2007. Data dalam Buku Peminjaman dan Pengembalian Buku itu menunjukkan jumlah rata-rata peminjam buku adalah tiga orang per hari dan pengunjung itu adalah siswa dan siswi SMP Alwasliyah 29. Buku-buku yang diminati adalah buku-buku pelajaran dan cerita agama. Akan tetapi pada waktu pengamatan tidak terlihat pengunjung TBM itu.

TBM ini dikelola oleh seorang ketua yang juga menjabat ketua PKBM Teladan dan seorang petugas penjaga yang masih kuliah di salah satu universitas swasta dekat TBM itu. Sejak berdiri petugas pelayanan telah berganti beberapa kali dan petugas yang ditemui baru bertugas sejak Agustus 2006. Oleh karena baru bertugas sekitar satu setengah tahun, yang bersangkutan tidak bisa memberikan data dan informasi yang lengkap mengenai sumber bahan bacaan serta upaya-upaya lain yang dilakukan oleh TBM Teladan. Yang bersangkutan juga belum pernah mengikuti penataran atau pelatihan tentang pengelolaan TBM atau perpustakaan.

\section{LPNF TBM PLUS MAS RADEN}

TBM yang semula bernama TBM MAS RADEN ini didirikan April 2003 dengan lokasi di Medan Perjuangan dan tiga tahun kemudian (April 2006) pindah ke Jl. Karya Jaya No. 192, Medan Johor. Bangunan yang ditempati berbentuk toko dengan ukuran $8 \times 16$ meter dengan dinding papan, lantai semen, dan atap seng. Bangunan ini menghadap jalan raya yang ramai lalu lintas dan pada awalnya di sewa dan dipergunakan oleh dua pedagang, pedagang jamu dan pedagang sate. Ruangannya dibagi dua dengan sekat pemisah. Satu ruang dipergunakan untuk jualan jamu disertai dengan penyewaan bahan bacaan dan satu ruangan dipergunakan untuk jualan sate oleh pedagang yang berbeda. Sambil minum jamu, pengunjung melihat-lihat, dan membaca-baca buku yang disewakan. Lama kelamaan perhatian pengunjung lebih banyak pada bahan bacaan meskipun jamu masih tetap ditawarkan.

TBM ini berubah nama menjadi Lembaga Pendidikan Nonformal (LPNF) TBM PLUS MAS RADEN mulai Maret 2007 sesuai dengan yang tertera dalam akte notaris pendiriannya. Perubahan nama ini dikaitkan dengan pengembangan kegiatan TBM yang tidak hanya sebagai tempat membaca dan meminjam bahan bacaan akan tetapi juga memberikan pelayanan bagi anggotanya yang mengalami kesulitan memperoleh sumber-sumber belajar. Kelebihannya juga terlihat dari adanya kegiatan warung jamu Nyonya Raden di dalam TBM ini serta penyediaan kaca mata plus bagi mereka yang memerlukannya.

Berawal dari koleksi buku keluarga, kini TBM ini memiliki 1.450 judul dengan jumlah keseluruhan 11.500 eksemplar bahan bacaan yang ditata menurut jenis buku dalam 13 rak dan lemari buku. Bahan bacaan itu terdiri atas 1.000 judul buku agama, 50 judul buku untuk perguruan tinggi, 100 judul untuk pelajar, 100 judul majalah dan 200 judul lainnya bahan bacaan umum seperti novel dan komik. Koleksi buku ini diperkaya rata-rata dua kali seminggu dengan membeli sekitar 30 judul bahan bacaan baru dan bekas dengan nilai antara Rp 250.000 sampai $R p$ 300.000. Di samping dalam bentuk buku dan majalah, TBM ini juga memiliki bahan informasi dalam bentuk poster, brosur, peta, CD, dan VCD. Ke depan TBM ini diarahkan ke TBM yang berbasis teknologi informasi. 
Untuk keperluan membaca disediakan 10 meja dan 30 kursi, untuk pengunjung disediakan satu buah toilet dan kamar mandi. TBM ini mulai beroperasi setiap hari dengan jam pelayanan Senin sampai Kamis, mulai pukul 2.00 siang sampai pukul 2.00 pagi dan pada hari Jumat sampai Minggu mulai pukul 12.00 siang sampai jpukul 2.00 pagi.Waktu buka ini disesuaikan dengan waktu lenggang kebanyakan pengunjung.

Berdasarkan data Desember 2006 jumlah anggota TBM ini mencapai 1.237 orang terdiri atas berbagai kalangan masyarakat. Masing-masing anggota dilengkapi dengan kartu anggota. Rata-rata jumlah pengunjung setiap hari mencapai 50 orang yang terdiri atas pedagang, pegawai, ibu-ibu rumah tangga, pelajar, dan mahasiswa. Mereka datang pada umumnya untuk membaca di tempat dan meminjam bahan bacaan. Sebagian (50\%) dari pengunjung meminjam bahan bacaan untuk jangka waktu peminjaman antara satu sampai tiga hari. Pengunjung yang membaca buku di TBM tidak dikenakan biaya sedangkan yang meminjam buku dikenakan biaya Rp 1.000 sampai Rp 2.000 bergantung pada ketebalan bahan bacaan yang dipinjam. Akan tetapi, apabila peminjam mengembalikan buku melewati batas waktu pengembalian, dikenakan denda yang jumlahnya sesuai dengan keikhlasan pengunjung dan dimasukkan ke dalam kotak infak. Pada waktu tertentu denda itu dikumpulkan dan disumbangkan ke mesjid, panti asuhan dan fakir miskin. Sedangkan dana yang diperoleh dari penyewaan buku itu dipergunakan untuk biaya operasional TBM serta untuk pembelian bahan bacaan.

Dokumen data pendukung anggota TBM ditata dan diarsipkan dalam file khusus. Sedangkan data koleksi bahan bacaan serta daftar pengunjung dan peminjam dicatat dalam buku tersendiri. Dana yang diperoleh melalui penyewaan dan penjualan buku dan majalah serta denda keterlambatan pengembalian bahan bacaan dibukukan dalam dokumen yang terpisah sehingga memudahkan pemantauan dan pemeriksaan sewaktu-waktu diperlukan.

Di samping memberikan pelayanan membaca, meminjamkan, dan menjual bahan bacaan sesuai dengan kebutuhan pengunjung, TBM ini menyelenggarakan promosi untuk meningkatkan minat dan kegemaran membaca melalui undian berhadiah, Lomba Apresiasi Sastra Indonesia mulai dari tingkat anak-anak, remaja, dan orang dewasa, Pemilihan Bintang Learning Society yang didasarkan jumlah buku yang dibaca. Promosi lain yang terlihat adalah sejumlah spanduk di depan dan di dalam bangunan TBM serta spanduk yang terbentang di atas jalan yang ramai lalu lintas itu. TBM ini juga melayani pesanan buku dan majalah yang dibutuhkan pengunjung.

LPNF TBM PLUS MAS RADEN dikelola oleh satu keluarga yang terdiri atas ibu rumah tangga sebagai pemilik/pengelola, seorang anak putri sebagai sekretaris/bendahara, dan kepala keluarga sebagai konsultan/pustakawan. Ketika pengamatan dilakukan, hanya konsultan/pustakwan itu yang terlihat dan yang sekaligus sebagai narasumber. Yang bersangkutan yang memiliki latar belakang pendidikan S1 di bidang pendidikan dan hukum itu masih berstatus pegawai negeri dan pernah menduduki jabatan eselon IV dan III dengan tugas yang terkait dengan pendidikan luar sekolah.

Data dan informasi yang diperoleh menggambarkan (a) organisasi, (b) sarana, (c) kegiatan, dan (d) tenaga pengelola keempat TBM yang diamati. 1. Organisasi.

Kecuali LPNF TBM PLUS MAS RADEN, ketiga TBM lainnya adalah bentukan PKBM dengan waktu pendirian berbeda-beda. TBM yang tertua sampai yang termuda adalah TBM TELADAN (1998), TBM KURSUS KOMPUTER PAKPAK MANDIRI (2000), TBM EMPHATY (2002) dan LPNF TBM PLUS MAS RADEN ( 2003), Akan tetapi usia TBM itu tidak memberikan pengaruh positif kekayaan jenis dan jumlah bahan bacaan yang dimiliki serta jenis pelayanan dan kegiatan yang dilakukan. LPNF TBM PLUS MAS RADEN ( 2003) yang merupakan TBM termuda memiliki koleksi yang terbanyak, kegiatan serta pelayanan yang bervariasi serta jumlah pengunjung yang terbanyak.

Keempat TBM yang diamati dikelola oleh tiga orang petugas, walaupun ketika dilakukan pengamatan ditemui hanya satu orang petugas. Tidak terlihat kesibukan petugas kecuali di LPNF TBM PLUS MAS RADEN, yang melayani pengunjung sambil diwawancarai. Sungguhpun pembagian tugas dirumuskan secara jelas dan berbeda satu sama lain tetapi tidak terlihat dilaksanakan secara nyata.

\section{Sarana}

Sarana yang tersedia di masing-masing terlihat bervariasi. Jumlah dan jenis bahan bacaan tersedia di TBM EMPHATY, TBM KURSUS KOMPUTER PAKPAK MANDIRI dan TBM TELADAN sangat sedikit.Di samping itu meja baca dan kursi tempat duduk untuk keperluan membaca juga kurang memadai. Keadaan ini dapat mengakibatkan kurangnya pengunjung dan peminjam bahan bacaan di ketiga TBM itu. Pengunjung dan peminjam ke masing-masing TBM itu hanya warga belajar Program Paket A, B, atau C serta di TBM TELADAN. Ditambah dengan beberapa siswa dan siswa SMP Alwasliyah 29. Di ketiga TBM itu tidak terlihat 
data pengunjung dari masyarakat umum, di luar warga belajar.

Di LPNF TBM PLUS MAS RADEN koleksi bahan bacaan jauh lebih lengkap, bervariasi serta memperhatikan kebutuhan pengunjung serta tersedia meja dan kursi baca dalam jumlah yang memadai di tambah lagi disediakannya toilet dan kamar mandi untuk pengunjung, mampu menarik lebih banyak pengunjung dan beroperasi sampai tengah malam.

\section{Kegiatan.}

Kegiatan utama di masing-masing TBM adalah memberikan pelayanan bahan bacaan untuk masyarakat. Tetapi kegiatan itu ternyata dilakukan terbatas sekali dilihat dari data jumlah pengunjung dan peminjam bahan bacaan di TBM EMPHATY, TBM KURSUS KOMPUTER PAKPAK MANDIRI dan TBM TELADAN. Di tiga TBM juga tidak terlihat kegiatan untuk mempromosikan minat dan kegemaran membaca serta bersifat menunggu dan tidak proaktif. Bentuk tulisan dan warna tinta data pengunjung/peminjam di dua TBM adalah sama. Dikhawatirkan data itu bukan sesungguhnya dan dibuat semata-mata untuk keperluan tertentu. Dengan demikian sulit dapat diharapkan ketiga TBM itu berfungsi sebagai (1) sarana pembelajaran bagi masyarakat, (2) sarana hiburan (rekreasi) dan pemanfaatan waktu secara efektif, dan (3) sarana informasi berupa buku dan bahan bacaan lain yang sesuai dengan kebutuhan warga belajar dan masyarakat setempat.

Kegiatan di LPNF TBM PLUS MAS RADEN sungguh berbeda. Di tempat ini selain memberikan pelayanan membaca di tempat dan meminjamkan bahan bacaan, dilakukan juga kegiatan untuk menarik minat baca pengunjung melalui penyelengaraan undian, berbagai lomba dan promosi melaui poster, spanduk, dan media massa. Di samping itu TBM ini memberikan bantuan bagi mereka yang mengalami kesulitan membaca atau kesulitan menemukan bahan bacaan Pengayaan koleksi secara teratur dan disesuaikan dengan kebutuhan masyarakat pengunjung juga ikut meningkatkan jumlah pengunjung mulai dari siswa sekolah dasar dan menengah, guru, mahasiswa, pedagang, dan ibu-ibu rumah tangga dari lingkungan maupun di luar lingkungan lokasi TBM itu. Dengan kegiatan yang demikian, TBM ini dapat diharapkan memberikan peranan untuk (1) membangkitkan dan meningkatkan minat baca masyarakat sehingga tercipta masyarakat cerdas yang selalu mengikuti perkembangan ilmu pengetahuan dan teknologi; (2) menjadi sebuah wadah kegiatan belajar masyarakat; dan (3) mendukung peningkatan kemampuan aksarawan baru.

\section{Tenaga Pengelola.}

Masing-masing TBM memiliki jumlah pengelola yang sama yaitu tiga orang.akan tetapi pembagian tugas untuk masing-masing orang berbeda antar TBM. Latar belakang pendidikan dan pengalaman masing-masing pengelola di keempat TBM juga berbeda-beda. Tenaga pengelola di TBM EMPHATY dan LPNF TBM PLUS MAS RADEN, masing-masing mempunyai hubungan keluarga, khususnya di LPNF TBM PLUS MAS RADEN. Sedangkan di TBM KURSUS KOMPUTER PAKPAK MANDIRI dan TBM TELADAN, tidak terlihat hubungan keluarga antar pengelolanya.

Pengelola di keempat TBM belum pernah mengukti pelatihan pengelolaan TBM atau perpustakaan. Akan tetapi pengelola di LPNF TBM PLUS MAS RADEN sangat berbeda dengan ke tiga pengelola lainnya. Walaupun pengelola di LPNF TBM PLUS MAS RADEN belum pernah mengikuti pelatihan pengelolaan TBM atau perpustakaan, TBM ini berawal dari koleksi bahan bacaan yang dimiliki keluarga yang berarti keluarga ini memiliki minat dan kegemaran membaca yang kemudian ditularkan ke orang lain melalui pendirian TBM. Di samping itu kepala keluarga yang mempunyai kedudukan sebagai konsultan/ pustakawan di TBM itu, bekerja sebagai tenaga kependidikan khususnya di bidang pendidikan luar sekolah dan memahami serta menghayati benar pentingnya membaca untuk mengembangkan potensi diri. Pengalaman pendidikan dan bekerjanya juga nampaknya memuat dia kreatif dan inovatif dalam memasyarakatkan gemar dan kebiasaan membaca.

Bendaharawan TBM ini adalah salah satu putri keluarga ini yang sedang kuliah di salah satu perguruan tinggi. Pengalaman belajarnya termasuk dalam menggunakan perpustakaan selama di sekolah dan perguruan tinggi mendorongnya untuk ikut menata TBM ini dengan teratur, rapi, dan nyaman untuk tempat membaca dan meminjam buku.

LPNF TBM PLUS MAS RADEN telah menerima berbagai bentuk bantuan termasuk dana dari Pemerintah, tetapi dana itu dipergunaannya untuk memperkaya koleksi TBM-nya sehingga menurut taksirannya koleksi TBM ini udah bernilai lebih dari Rp.100.000 dan sebagian besar merupakan usaha swadaya. Sedangkan bantuan yang diterima keempat TBM lainnya melalui PKBM yang menaunginya tidak terlihat secara nyata untuk pengembangan koleksi dan kegiatan TBM itu.

Dari data dan informasi yang diperoleh terlihat latar belakang pengalaman, pendidikan dan motivasi pengelola TBM dapat mendorong kreativitas dan inovasi dalam mengelola dan mengembangkan TBM sehingga 
dapat berperan secara berarti dalam mewujudkan masyarakat gemar belajar dan gemar membaca. Lokasi, sarana, dan dana memang dibutuhkan dalam mengembangkan TBM, akan tetapi akan bermakna banyak apabila TBM itu dikelola oleh petugas yang memiliki wawasan yang benar tentang tugas, fungsi, dan tujuan TBM serta dibarengi dengan motivasi dan dedikasi yang tinggi. Untuk mewujudkan sumber daya yang demikian Pemerintah atau instansi lain yang memberikan bantun ke TBM perlu memprioritaskan bantuannya untuk penyelenggaraan pelatihan pengelola TBM. Ungkapan yang mengatakan bahwa kegiatan dan pencapaian tujuan bergantung pada the man behind the gun, juga berlaku untuk pengelolaan TBM ini. Kreativitas pengelola membuat TBM lebih bergairah.

\section{KESIMPULAN}

Seperti diuraikan sebelumnya bahwa penelitian pendahuluan ini diharapkan dapat memberikan gambaran tentang (1) sarana, (2) kegiatan, (3) jumlah tenaga pengelola, dan (4) kemampuan pengelola di keempat TBM yang di amati. Data, informasi, dan pembahasan yang telah dipaparkan dapat disimpulkan bahwa jumlah dan jenis bahan bacaan serta sarana untuk membaca di ketiga TBM (di luar LPNF TBM PLUS MAS RADEN) sangat minim dan kurang dapat memenuhi kebutuhan masyarakat sekitarnya serta tidak mendukung untuk meumbuhkembangkan minat dan kegemaran membaca. Sementara itu koleksi baha bacaan dan sarana membaca di LPNF TBM PLUS MAS RADEN dapat dkatakan cukup lengkap dan dapat menarik minat dan menumbuhkan kebiasaan membaca masyarakat sekitarnya.

Kegiatan di ketiga TBM sangat terbatas pada pelayanan dan bahan bacaan yang jumlah dan jenisnya sangat terbatas sehingga tidak mampu menarik banyak pengunjung dan peminjam. Berbeda dengan dengan di LPNF TBM PLUS MAS RADEN yang melakukan berbagai kegiatan berkaitan dengan promosi minat dan gemar membaca, di samping pelayanan membaca gratis dan meminjam bahan bacaan. TBM ini berhasil menarik jauh lebih banyak pengunjung dan peminjam buku dari berbagai kalangan di masyarakat.

Sungguhpun struktur organisasi dan jumlah pengelola keempat TBM yang diamati adalah sama, akan tetapi pengelola di LPNF TBM PLUS MAS RADEN mempunyai latar belakang pengalaman dan pendidikan yang berbeda serta memiliki penghayatan akan tugastugasnya serta motivasi yang tinggi untuk kreatif dan inovatif dalam melaksanakan tugas dan fungsi TBM dalam mewujudkan masyarakat gemar membaca dan gemar belajar. Oleh karena itu, pengetahuan tentang tugas, fungsi, dan tujuan TBM serta keterampilan mengelola TBM sangat diperlukan dalam memberdayakan TBM.

Memperhatikan keadaan di keempat TBM yang diamati nampaknya semua pihak, termasuk Pemerintah, yang ingin memberikan bantuan ke TBM, hendaknya menarahkan bantuan itu pada peningkatan mutu pengelola TBM dengan memberikan kemampuan dan keterampilan pengellaan TBM melalui pelatihan atau pendidikan di samping meningkatkan motivasi mereka melalui Motivation Managament Training dan Achievement Management Training.

\section{DAFTAR PUSTAKA}

Direktorat Pendidikan Masyarakat. (2006). Pedoman pengelolaan Taman Bacaan Masyarakat (TBM). Jakarta: Direktorat Pendidikan Masyarakat, Direktorat Pendidikan Luar Sekolah, Departemen Pendidikan Nasional.

Direktorat Pendidikan Masyarakat. (2006). Pedoman penyelenggaraan Taman Bacaan Masyarakat. Jakarta: Direktorat Pendidikan Masyarakat, Direktorat Pendidikan Luar Sekolah, Departemen Pendidikan Nasional.

Direktorat Pendidikan Masyarakat. (2006). Membaca jadikan kualitas hidup lebih baik. Brosur Jakarta: Direktorat Pendidikan Masyarakat, Direktorat Pendidikan Luar Sekolah, Departemen Pendidikan Nasional.

"Minat baca: Akses buku bagi anak miskin terbatas".
Kompas, 26 Mei 2006, 12.

"Publik dan buku: Jajak pendapat Kompas Perpustakaan miskin peminat". Kompas, 19 Maret 2005, 52.

Supriyoko, K. (2005). "Minat baca dan kualitas bangsa", dari, http://smp.-alkausar.org/detail-artikel.php?id=118.

Wendyartaka, A. (2005). "Minat baca masyarakat terhadang daya beli. Kompas, 19 Februari 2005.

(2004). Education for all: Global monitoring report 2005. UNESCO.

(2005) Rencana Strategis Departemen Pendidikan Nasional tahun 2005-2009 (RPJMN 20052009), IKAPI pada tahun 2005. 